Prepared in collaboration with the U.S. Fish and Wildlife Service

\title{
Determination of Selenium in Fish from Designated Critical Habitat of the Gunnison River, Colorado, Summer 2011
}

Open-File Report 2012-1235 



\section{Determination of Selenium in Fish from Designated Critical Habitat of the Gunnison River, Colorado, Summer 2011}

By Thomas W. May and Michael J. Walther

Prepared in collaboration with the U.S. Fish and Wildlife Service

Open-File Report 2012-1235 


\title{
U.S. Department of the Interior \\ KEN SALAZAR, Secretary \\ U.S. Geological Survey \\ Marcia K. McNutt, Director
}

\author{
U.S. Geological Survey, Reston, Virginia: 2012
}

For more information on the USGS - the Federal source for science about the Earth, its natural and living resources, natural hazards, and the environment, visit http://www.usgs.gov or call 1-888-ASK-USGS.

For an overview of USGS information products, including maps, imagery, and publications, visit http://www.usgs.gov/pubprod

To order other USGS information products, visit http://store.usgs.gov

Any use of trade, firm, or product names is for descriptive purposes only and does not imply endorsement by the U.S. Government.

Although this information product, for the most part, is in the public domain, it also may contain copyrighted materials as noted in the text. Permission to reproduce copyrighted items must be secured from the copyright owner.

Suggested citation:

May, T.W., and Walther, M.J., 2012, Determination of selenium in fish from designated critical habitat of the Gunnison River, Colorado, summer 2011: U.S. Geological Survey Open-File Report 2012-1235, 4 p. 


\section{Contents}

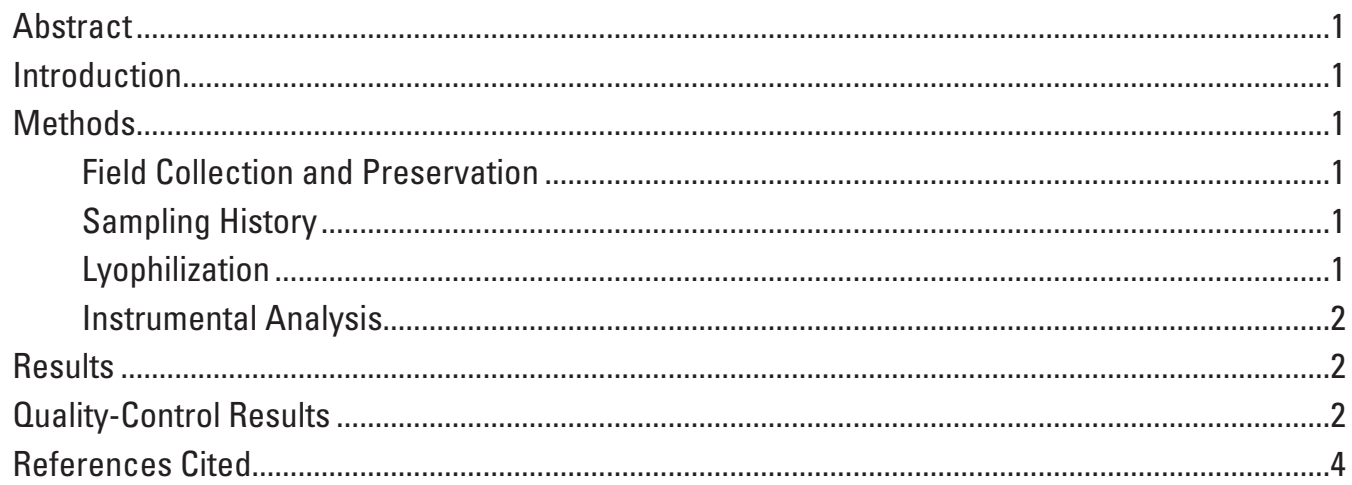

\section{Tables}

1. Concentrations of selenium in fish muscle plugs collected from fish inhabiting the Gunnison River in Western Colorado, summer 2011.

2. Selenium recoveries from a reference tissue material analyzed with fish muscle plug samples..

\section{Conversion Factors}

SI to Inch/Pound

\begin{tabular}{|c|c|c|}
\hline Multiply & By & To obtain \\
\hline \multicolumn{3}{|c|}{ Length } \\
\hline millimeter $(\mathrm{mm})$ & 0.03937 & inch (in.) \\
\hline \multicolumn{3}{|c|}{ Volume } \\
\hline liter (L) & 33.82 & ounce, fluid (fl. oz) \\
\hline milliliter $(\mathrm{mL})$ & 0.034 & ounce, fluid (fl. oz) \\
\hline \multicolumn{3}{|c|}{ Mass } \\
\hline $\operatorname{gram}(\mathrm{g})$ & 0.03527 & ounce, avoirdupois (oz) \\
\hline milligram (mg) & 0.000035 & ounce, avoirdupois (oz) \\
\hline microgram $(\mu \mathrm{g})$ & 0.000000035 & ounce, avoirdupois (oz) \\
\hline
\end{tabular}

Temperature in degrees Celsius $\left({ }^{\circ} \mathrm{C}\right)$ may be converted to degrees Fahrenheit $\left({ }^{\circ} \mathrm{F}\right)$ as follows:

$$
{ }^{\circ} \mathrm{F}=\left(1.8 \times{ }^{\circ} \mathrm{C}\right)+32
$$

Concentrations of chemical constituents in solid materials are given in micrograms per gram $(\mu \mathrm{g} / \mathrm{g})$ dry weight. 



\title{
Determination of Selenium in Fish from Designated Critical Habitat of the Gunnison River, Colorado, Summer 2011
}

\author{
By Thomas W. May and Michael J. Walther
}

\begin{abstract}
This report presents results for the summer 2011 sampling of muscle plugs from common carps (Cyprinus Linnaeus), roundtail chub (Gila robusta), and bonytail chub (Gila elegans) inhabiting critical habitat in the Gunnison River in Western Colorado. Total selenium in fish muscle plugs was determined by instrumental neutron activation analysis. Total selenium concentrations (range and mean \pm standard deviation) in micrograms per gram dry weight for each species were as follows: common carp: 8.5 to $35,13 \pm 7.8$; roundtail chub: 5.5 to $11.2,7.3 \pm 1.6$; bonytail chub: 0.8 to $8.6,3.9 \pm$ 4.2. Selenium concentrations in muscle plugs from 4 out of 15 roundtail chub, all 15 common carp, and 2 out of 5 bonytail chub exceeded the 8 micrograms per gram dry weight toxicity guideline for selenium in fish muscle tissue.
\end{abstract}

\section{Introduction}

Irrigation drainage from large irrigation projects in the Uncompahgre and Grand Valley in western Colorado has resulted in selenium (Se) loading into the Uncompahgre, Gunnison and Colorado Rivers that exceeds the 5 micrograms per liter (ug/L) aquatic life protection standard established in 1977 by the Colorado Water Quality Commission (Colorado Department of Public Health and Environment, 2007). Within this area, the lower Gunnison River and the Colorado River are designated critical habitat for the endangered Colorado pikeminnow (Ptychocheilus lucius), razorback sucker (Xyrauchen texanus), and bonytail chub (Gila elegans). There is concern that high selenium concentrations in water, sediment, and biota collected from these rivers also are adversely affecting these endangered fish species (Hamilton, 1998). In collaboration with the Colorado River Recovery Program, the U.S. Fish and Wildlife Service (USFWS) monitors endangered fish populations in the Lower Gunnison River as well as selenium concentrations in fish through the use of non-lethal muscle plug biopsies (Osmundson and others, 2000). The USFWS has sought collaboration from the U.S. Geological
Survey (USGS) for the determination of selenium in muscle plug samples. This report includes results for the analysis of selenium in muscle plugs of common carp, roundtail chub, and bonytail chub collected during the summer of 2011 from a lower stretch of designated critical habitat in the Gunnison River between Escalante and the Colorado River confluence.

\section{Methods}

\section{Field Collection and Preservation}

Muscle plug samples were taken with a biopsy punch from live specimens of common carp, roundtail chub, and bonytail chub collected from the Gunnison River between Escalante (river mile 44.1) and the Colorado confluence (river mile 0.7). Samples were placed in cryotubes, enclosed in a Whirl-Pak ${ }^{\circledR}$ bag, and frozen on dry ice. All samples were collected by USFWS personnel in August of 2011. Samples were stored in a freezer until shipment to the USGS.

\section{Sampling History}

The muscle plug samples collected by USFWS personnel were received in one shipment by the Environmental Chemistry Branch Inorganic Section (henceforth referred to as "the laboratory") of the USGS shortly after collection on August 31, 2011, and contained 17 common carp muscle plugs, 15 roundtail chub muscle plugs, and 5 bonytail chub muscle plugs.. The samples were assigned USGS batch number 1941 and USGS sample identification numbers 55406 to 55442 . Selenium was to be determined in all samples by instrumental neutron activation analysis (INAA).

\section{Lyophilization}

All sample preparation before INAA was conducted by USGS at the Columbia Environmental Research Center in Columbia, Missouri in collaboration with the University of 
Missouri Research Reactor (MURR). The entire plug was transferred from its original cryotube container into a $1.5 \mathrm{~mL}$ polyethylene vial provided by MURR staff. Vials were precleaned by stepwise washing with acetone, nitric acid, and deionized water. Each sample was positioned and pressed flat against the vial bottom with a cleaned glass rod. All vials were left open and placed in the tray chamber of a Virtis Genesis 35EL lyophilizer in "shelf" control and frozen to -75 degrees Celsius $\left({ }^{\circ} \mathrm{C}\right)$. Once a condenser temperature of $-70^{\circ} \mathrm{C}$ and vacuum of 300 milliTorr was reached, the drying cycle commenced. All muscle plug samples were lyophilized to constant weight, and dried weights ranged from 20.8 to 60.1 milligrams (mg) and averaged $41.4 \mathrm{mg}$. Lyophilization greatly reduces the oxygen-19 radioisotope $\left({ }^{19} \mathrm{O}\right)$ from water in the irradiated sample, and markedly enhances measurement precision. Upon recording of final sample weight, an expandable, cleaned polyethylene plug was inserted into the vial against which the vial lid was compressed shut. All samples were transported to MURR for the determination of selenium.

\section{Instrumental Analysis}

Standards in the range of 0.01 to 5 micrograms $(\mu \mathrm{g})$ selenium were prepared by pipetting the appropriate quantities from a series of selenium stock solutions dried onto filter pulp paper which was comparable in geometric configuration to that of the samples. The pulp paper was then placed in the bottom of the polyethylene vials. A National Institutes of Standards and Technology (NIST) lyophilized Standard Reference Material (SRM) 1577 Bovine Liver also was run as a MURR internal quality control sample. All standards and samples were analyzed for selenium by way of ${ }^{77 \mathrm{~m}} \mathrm{Se}$ using the following nuclear reaction: ${ }^{76} \mathrm{Se}(\mathrm{n}, \gamma) 77 \mathrm{mSe}$ and ${ }^{77 \mathrm{~m}} \mathrm{Se} \rightarrow{ }^{77 \mathrm{~m}} \mathrm{Se}+\gamma$ and measuring the 161.9 kiloelectron volt $(\mathrm{keV})$ gamma-ray. Each standard or sample was placed in the top-center position of a shuttle rabbit and irradiated for 5.00 seconds in the Row I position using the pneumatic-tube irradiation facility at MURR. This position has thermal and epithermal neutron flux densities of $8 \times 10^{13}$ neutrons $\mathrm{x}$ centimeter ${ }^{-2} \mathrm{x}$ second $^{-1}$ and $2 \mathrm{x}$ $10^{12}$ neutrons $\mathrm{x}$ centimeter ${ }^{-2} \mathrm{x}$ second ${ }^{-1}$. The pneumatic transfer facility used has a delivery time to the counting station of about 4 seconds. The returned shuttle rabbit was quickly opened and the sample vial transferred to a special holder that positions the small polyethylene vial on the face of the detector. All samples were analyzed using a 5 -second irradiation, 15-second decay, and 25-second real-time count using a high resolution gamma-ray spectrometer. The gamma-ray spectrometer included a Tennelec 244 amplifier coupled to a Nuclear Data 599 loss-free counting module and a Nuclear Data 581 ADC. Data acquisition and peak extraction were done using a VAX station 3100, model 38 with Canberra/ND applications software. The $161.9 \mathrm{keV}$ gamma-ray from the decay of ${ }^{77 \mathrm{~m}} \mathrm{Se}$ was used to determine selenium concentrations by standard comparison (Spate and others, 1994; Baskett and others, 2001).

\section{Results}

Total selenium concentrations [micrograms per gram dry weight, $(\mu \mathrm{g} / \mathrm{g})]$ in fish muscle plug samples collected from fish inhabiting the Gunnison River in Western Colorado are listed in table 1. Total selenium concentrations [range and mean \pm standard deviation (SD)] in $\mu \mathrm{g} / \mathrm{g}$ dry weight for each species were as follows: common carp: 8.5 to $35,13 \pm 7.8$; roundtail chub: 5.5 to $11.2,7.3 \pm 1.6$; bonytail chub: 0.8 to $8.6,3.9 \pm$ 4.2. Selenium concentrations in muscle plugs from 4 out of 15 roundtail chub, all 15 common carp, and 2 out of 5 bonytail chub exceeded the $8 \mu \mathrm{g} / \mathrm{g}$ dry weight toxicity guideline (Lemly, 2002) for selenium in fish muscle tissue.

\section{Quality-Control Results}

Concentrations ( $\mu \mathrm{g} / \mathrm{g}$ dry weight) of selenium in National Institute of Standards and Technology (NIST) Standard Reference Material (SRM) 1577 Bovine Liver $(n=4)$ averaged 1.14 and ranged from 1.13 to 1.17 with an SD of $0.021 \mu \mathrm{g} / \mathrm{g}$ (table 2). Compared with the certified selenium concentration, these results expressed a selenium recovery of 104 percent with a percent relative standard deviation of 1.8 . 
Table 1. Concentrations of selenium in fish muscle plugs collected from fish inhabiting the Gunnison River in Western Colorado, summer 2011.

[USGS, United States Geological Survey; ID, identification; $\mu \mathrm{g} / \mathrm{g}$, micrograms per gram dry weight]

\begin{tabular}{|c|c|c|c|c|c|}
\hline USGS ID & Field ID & $\begin{array}{c}\text { Fish } \\
\text { common name }\end{array}$ & $\begin{array}{l}\text { Collection } \\
\text { date }\end{array}$ & $\begin{array}{l}\text { Percent } \\
\text { moisture }\end{array}$ & $\begin{array}{c}\text { Selenium } \\
(\mu \mathrm{g} / \mathrm{g})\end{array}$ \\
\hline 55406 & GIICCP1 & Common carp & $08 / 19 / 11$ & 72.5 & 10.2 \\
\hline 55407 & GIICCP2 & Common carp & 08/18/11 & 79.3 & 12.2 \\
\hline 55408 & GIICCP3 & Common carp & 08/18/11 & 78.5 & 8.50 \\
\hline 55409 & GIICCP4 & Common carp & 08/18/11 & 79.4 & 10.2 \\
\hline 55410 & GIICCP5 & Common carp & $08 / 17 / 11$ & 77.9 & 10.6 \\
\hline 55411 & GIICCP6 & Common carp & $08 / 19 / 11$ & 77.5 & 10.0 \\
\hline 55412 & GIICCP7 & Common carp & $08 / 19 / 11$ & 79.0 & 10.9 \\
\hline 55413 & GIICCP8 & Common carp & 08/19/11 & 70.7 & 8.45 \\
\hline 55414 & GIICCP9 & Common carp & $08 / 17 / 11$ & 78.0 & 9.74 \\
\hline 55415 & GIICCP10 & Common carp & $08 / 17 / 11$ & 82.3 & 32.2 \\
\hline 55416 & GIICCP11 & Common carp & $08 / 18 / 11$ & 76.4 & 10.5 \\
\hline 55417 & GIICCP12 & Common carp & 08/19/11 & 76.7 & 10.9 \\
\hline 55418 & GIICCP13 & Common carp & $08 / 19 / 11$ & 77.4 & 11.6 \\
\hline 55419 & GIICCP14 & Common carp & $08 / 19 / 11$ & 72.0 & 9.67 \\
\hline 55420 & GIICCP15 & Common carp & $08 / 18 / 11$ & 79.7 & 11.0 \\
\hline 55421 & GU-BTMP3 & Bonytail & $08 / 23 / 11$ & 72.3 & 0.81 \\
\hline 55422 & GU-BTMP3B & Bonytail & $08 / 23 / 11$ & 74.4 & 0.89 \\
\hline 55423 & GII-RTC1 & Roundtail chubs & $08 / 17 / 11$ & 79.4 & 5.62 \\
\hline 55424 & GII-RTC2 & Roundtail chubs & $08 / 18 / 11$ & 80.0 & 6.17 \\
\hline 55425 & GII-RTC3 & Roundtail chubs & 08/17/11 & 80.4 & 7.06 \\
\hline 55426 & GII-RTC4 & Roundtail chubs & $08 / 19 / 11$ & 80.7 & 8.47 \\
\hline 55427 & GII-RTC5 & Roundtail chubs & $08 / 17 / 11$ & 79.3 & 5.59 \\
\hline 55428 & GII-RTC6 & Roundtail chubs & $08 / 19 / 11$ & 80.0 & 8.94 \\
\hline 55429 & GII-RTC7 & Roundtail chubs & 08/19/11 & 79.8 & 7.86 \\
\hline 55430 & GII-RTC8 & Roundtail chubs & $08 / 19 / 11$ & 80.0 & 8.78 \\
\hline 55431 & GII-RTC9 & Roundtail chubs & $08 / 19 / 11$ & 79.9 & 7.80 \\
\hline 55432 & GII-RTC10 & Roundtail chubs & $08 / 19 / 11$ & 79.5 & 7.75 \\
\hline 55433 & GII-RTC11 & Roundtail chubs & $08 / 18 / 11$ & 80.7 & 5.50 \\
\hline 55434 & GII-RTC12 & Roundtail chubs & 08/19/11 & 80.7 & 11.2 \\
\hline 55435 & GII-RTC13 & Roundtail chubs & $08 / 18 / 11$ & 80.7 & 6.85 \\
\hline 55436 & GII-RTC14 & Roundtail chubs & $08 / 17 / 11$ & 79.7 & 5.45 \\
\hline 55437 & GII-RTC15 & Roundtail chubs & $08 / 18 / 11$ & 81.5 & 7.02 \\
\hline 55438 & GU-BTMP1 & Bonytail & $06 / 09 / 11$ & 80.5 & 8.34 \\
\hline 55439 & GU-BTMP2 & Bonytail & $08 / 19 / 11$ & 72.4 & 0.81 \\
\hline 55440 & GIICCP13B & Common carp & 08/18/11 & 77.7 & 11.1 \\
\hline 55441 & GIICCP10B & Common carp & $08 / 17 / 11$ & 81.8 & 35.1 \\
\hline 55442 & GU-BTMP4 & Bonytail & $08 / 29 / 11$ & 79.0 & 8.58 \\
\hline
\end{tabular}


Table 2. Selenium recoveries from a reference tissue material analyzed with fish muscle plug samples.

[MURR, University of Missouri Research Reactor; QC, quality control; ID, identification; $\mu \mathrm{g} / \mathrm{g}$, microgram per gram dry weight; SD, standard deviation; RSD, relative standard deviation; NIST, National Institute of Standards and Technology; --, not applicable]

\begin{tabular}{ccccccc}
\hline $\begin{array}{c}\text { MURR } \\
\text { OC ID }\end{array}$ & $\begin{array}{c}\text { Reference } \\
\text { material }\end{array}$ & $\begin{array}{c}\text { Certified } \\
\text { mange } \\
(\boldsymbol{\mu g} / \mathbf{g})\end{array}$ & $\begin{array}{c}\text { Selenium } \\
(\boldsymbol{\mu g} / \mathbf{g})\end{array}$ & $\begin{array}{c}\text { Mean } \\
(\boldsymbol{\mu g} / \mathbf{g})\end{array}$ & $\begin{array}{c}\text { SD } \\
(\boldsymbol{\mu g} / \mathbf{g})\end{array}$ & $\begin{array}{c}\text { Percent } \\
\text { RSD }^{\mathrm{a}}\end{array}$ \\
\hline BL-Z-11 & NIST $1577^{\mathrm{b}}$ & $1.1 \pm 0.1$ & 1.15 & 1.14 & 0.021 & 1.8 \\
BL-Z-12 & NIST $1577^{\mathrm{b}}$ & $1.1 \pm 0.1$ & 1.13 & -- & -- & - \\
BL-Z-15 & NIST $1577^{\mathrm{b}}$ & $1.1 \pm 0.1$ & 1.17 & -- & -- & - \\
BL-Z-16 & NIST $1577^{\mathrm{b}}$ & $1.1 \pm 0.1$ & 1.13 & -- & -- & - \\
\hline
\end{tabular}

${ }^{\mathrm{a} C a l c u l a t e d}$ as $\mathrm{SD} \div$ mean $\mathrm{x} 100$.

${ }^{\mathrm{b} S R M}$ 1577: bovine liver.

\section{References Cited}

Spate V.L., Mason M.M., Reams C.L., Baskett C.K., Morris J.S., Mills D.S., 1994, Determination of total and bound Se in sera by INAA: Journal of Radioanalytical and Nuclear Chemistry, v. 179 , no. 2, p. 315-322.

Hamilton, S.J., 1998, Selenium effects on endangered fish in the Colorado River Basin, in Frankenberger, W.T. Jr. and Engberg, R.A., eds. Environmental Chemistry of Selenium: Marcel Dekker, Inc., p. 297-313.

Osmundson, B., May, T.W., and Osmundson, D., 2000, Selenium concentrations in the Colorado pikeminnow (Ptychocheilus lucius) - Relationship with flows in the upper Colorado River: Archives of Environmental Contamination and Toxicology, v. 38, p. 479-485.
Baskett, C.K., Spate, V.L., Mason, M.M., Nichols, T.A., Williams, A., Dubman, I.M., Gidina, A., Denison, J., Morris, J.S., 2001, Long-term selenium status in humans: Journal of Radioanalytical and Nuclear Chemistry, v. 249, no. 2, p. $429-435$.

Lemly, D.A., 2002, Selenium assessment in aquatic ecosystems, Alexander, D.E., ed., in chap 2 of Springer Series on Environmental Management, Interpreting Selenium Concentrations: New York, Springer-Verlag, p. 18-38.

Colorado Department of Public Health and Environment (CDPHE), 2007, Classifications and numeric standards for Gunnison and lower Dolores River Basins, 5 CCR 1002-35, Regulation No. 35: Denver, Colo., Colorado Department of Public Health and Environment, Water Quality Control Commission, $72 \mathrm{p}$.

Publishing support provided by:

Rolla and Denver Publishing Service Centers

For more information concerning this publication, contact:

Director, USGS Columbia Environmental Research Center 4200 New Haven Road

Columbia, MO 65201

(573) 875-5399

Or visit the Columbia Environmental Research Center Web site at: http://www.cerc.usgs.gov/ 

